maturity has decreased for several other reasons. These include many changes in obstetric practice, and it is not possible to summarise the effect that all of these would be expected to exert on perinatal mortality, gestational age, and birth weight. Nevertheless, the broadly parallel trends in elective delivery and the incidence of preterm delivery or low birth weight tend to confirm the hypothesis put forward previously that the high rate of induction of labour during 1970-4 was the major reason for the high incidences of low birth weight and preterm delivery during that period.

\section{References}

${ }^{1}$ Newcombe RG, Chalmers I. Changes in distribution of gestational age and birth weight among firstborn infants of Cardiff residents. $\mathrm{Br} \mathrm{Med} \mathcal{f}$ 1977; ii :925-6.

${ }^{2}$ Andrews J, Davies K, Chalmers I, Campbell H. The Cardiff births survey. In: Harper PS, Sunderland E, eds. Genetic and population studies in Wales. Cardiff: University of Wales Press (in press).

3 Yudkin P. Problems in assessing effects of induction of labour on perinatal mortality. Br $\mathcal{F}$ Obstet Gynaecol 1976;83:603-7.

\title{
Excess mortality among children discharged from hospital after treatment for diarrhoea in rural Bangladesh
}

\author{
S K ROY, A K M A CHOWDHURY, M M RAHAMAN
}

\begin{abstract}
Five hundred and fifty one children aged between 3 months and 3 years were followed up at home for 12 months after treatment of diarrhoea in a rural treatment centre of the International Centre for Diarrhoeal Disease Research, Bangladesh. During follow up the children were found to have a significantly higher mortality than generally observed in the community. The first three months after discharge appeared to be crucial, some $\mathbf{7 0} \%$ of the deaths occurring in that period. Severely malnourished children (nutritional state below $56 \%$ of the American National Center for Health Statistics (NCHS) standard of weight for age ratio) had a risk of death 14 times that of their well nourished counterparts (nutritional state $66 \%$ or more of the NCHS standard). The highest mortality occurred in 2 year olds, one in three of the severely malnourished children dying compared with one in 10 of the moderately malnourished. This pattern was not seen in children aged under 2 years.

Immediate priority should be given to providing nutritional rehabilitation for malnourished children who contract diarrhoea.
\end{abstract}

\section{Introduction}

Diarrhoea and malnutrition continue to be the two most important factors associated with high mortality among children in developing countries. ${ }^{1}$ Several studies, based mostly on lay reporting, have shown a gross association between malnutrition and mortality. ${ }^{2}{ }^{3}$ To our knowledge there has been no longitudinal study to establish the role of malnutrition and its severity as a risk factor for increased fatality rates. Death, however, is a comparatively infrequent event in any community, and it is difficult to keep a large number of children under surveillance for nutritional state.

In Matlab, a rural area in Bangladesh, demographic surveillance has been continued since 1966 . This offered an opportunity to determine the nutritional state of children discharged from

\footnotetext{
International Centre for Diarrhoeal Disease Research, Bangladesh, GPO Box 128, Dhaka-2, Bangladesh

$S \mathrm{~K}$ ROY, MB, BS, senior medical officer

A K M A CHOWDHURY, D SC, scientist

M M RAHAMAN, MSC, PHD, senior scientist and deputy director

Correspondence to: Dr A K M A Chowdhury.
}

hospital after treatment for diarrhoea and to monitor this during follow up. We report such a study, which was designed to discover whether the nutritional state of children recently recovered from diarrhoea and sent back to their unprotected home environment plays a part in subsequent mortality due to reinfection during 12 months after discharge.

\section{Patients and methods}

The study was carried out in the rural area of Matlab, Bangladesh. In 1966 a longitudinal mandatory registration system was begun, which since 1978 has covered 177000 people living in the surrounding 149 villages. Detailed field techniques of demographic surveillance and the role of the diarrhoeal health service have been reported. ${ }^{4}$ A small fleet of speedboats is used to transport patients from their villages for treatment of diarrhoea.

We studied 551 children aged between 3 months and 3 years who in 1979 were admitted to Matlab treatment centre with the complaint of diarrhoea. Each child was weighed on admission and at discharge using an accurate balance (Toledo, USA). The children with diarrhoea were rehydrated with oral and intravenous solutions. Accurate age of the population was known from the special birth registration system in the area, ${ }^{4}$ so that estimation of nutritional state was expected to be free of the age related bias commonly encountered in developing countries. Nutritional state was determined by comparing actual weight at the time of discharge with the National Center for Health Statistics (NCHS) standard of median weight for age. ${ }^{5}$

The children were classified into three categories of nutritional state: normally nourished-those whose weight was $66 \%$ and above of the NCHS standard; moderately malnourished-children whose weight was $56-65 \%$ of the standard; and severely malnourishedchildren whose weight was below $56 \%$ of standard. Classification was based on a study of subsequent risk of mortality in children assessed for these anthropometric values in a rural community of Bangladesh. ${ }^{3}$ Data from that study (fig 1) showed that there was a threshold of about $65 \%$ of standard weight for age above which mortality was low and constant but below which mortality increased sharply. Use of the classification in this study was expected to have more functional value for Bangladesh than the traditional approach.

TABLE I-Distribution of children by age and nutritional state

\begin{tabular}{lrrrrrr}
\hline $\begin{array}{l}\text { Nutritional state } \\
\text { (\% NCHS } \\
\text { standard) }\end{array}$ & \multicolumn{5}{c}{ Age (months) } & Total \\
\cline { 2 - 5 } & $1-11$ & $12-23$ & $24-35$ & $36-47$ & \\
\hline 555 & 10 & 27 & 25 & 2 & 64 \\
$56-65$ & 39 & 85 & 29 & 7 & 160 \\
$\geqslant 66$ & 142 & 135 & 39 & 8 & 324 \\
Not known & 2 & & & 1 & 3 \\
\hline Total & 193 & 247 & 93 & 18 & 551 \\
\hline
\end{tabular}

NCHS $=$ National Center for Health Statistics 


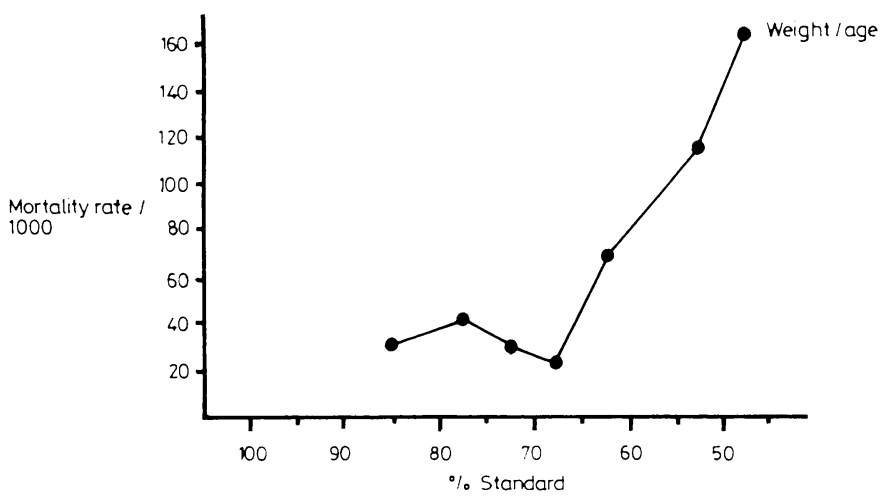

FIG 1 -Mortality rates 1000 in children assessed for percentage of Harvard standard of weight for age. (From Chen et al. ${ }^{3}$ )

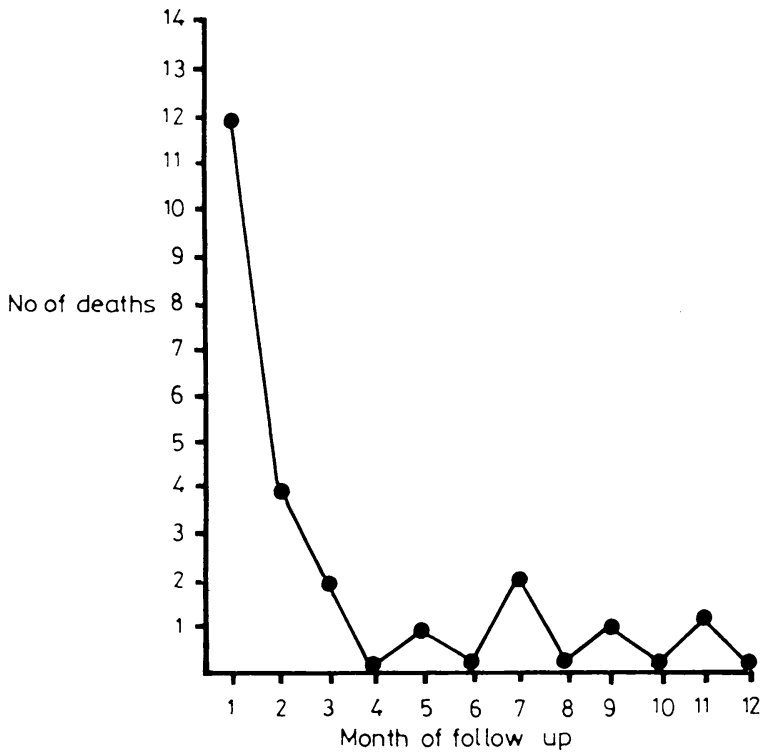

FIG 2-Distribution of deaths during 12 months of follow up.

TABLE II-Comparison of obserzed and expected numbers of deaths by age of children

\begin{tabular}{lcccc}
\hline $\begin{array}{l}\text { Age } \\
\text { months) }\end{array}$ & $\begin{array}{c}\text { No of } \\
\text { children } \\
\text { studied }\end{array}$ & $\begin{array}{c}\text { Population } \\
\text { death rate } \\
1979\end{array}$ & $\begin{array}{c}\text { Expected } \\
\text { deaths in } \\
12 \text { months }\end{array}$ & $\begin{array}{c}\text { Observed } \\
\text { deaths during } \\
12 \text { months }\end{array}$ \\
\hline $1-11$ & 193 & $43 \cdot 3$ & $8 \cdot 4$ & 6 \\
$12-23$ & 247 & $33 \cdot 3$ & $8 \cdot 2$ & 6 \\
$24-35$ & 93 & $23 \cdot 0$ & $2 \cdot 1$ & $11^{*}$ \\
$36-47$ & 18 & $16 \cdot 0$ & $0 \cdot 3$ & \\
\hline
\end{tabular}

$* Z=6 \cdot 13 ; p \cdot 0 \cdot 001$

\section{Results}

Table I shows the age and nutritional state of the 551 children at the time of discharge. A total of $64\left(12^{\circ}\right)$ were below $56^{\prime \prime}$ "of the NCHS standard. This group accounted for $5^{\circ}$ of all children aged under 1 year, $11^{\circ}$ o of those aged 1 year, and $27^{\circ}$ of children aged 2 years.

Table II gives the observed and expected numbers of deaths of the children in each age group during the 12 months after discharge from the treatment centre. The expected numbers of deaths were calculated from the age specific mortality rate of the community in the same year. ${ }^{6}$ Only a slight difference was observed between expected and actual deaths among children aged less than 12 months and 12 to 23 months. In children aged 24 to 35 months ( 2 year age group), however, mortality was five times higher than that of children of similar age in the community $(Z=6 \cdot 13 ; p<0 \cdot 001)$. There were only 18 children in the 3 year age group (36-47 months), which was considered too small a sample to reflect any definite pattern.

In the study group as a whole, 23 of the children $(4 \cdot 2 \%)$ died during the follow up period. Sixteen of these deaths $\left(70^{\prime \prime}\right)$ occurred in the $Z$ first three months, which was therefore identified as a "high risk" $\mathbb{\mathbb { Q }}$ period (fig 2). Figure 3 shows the yearly mortality rates (per 1000) observed in the children under study according to their nutritional $\widehat{\Omega}$ states. Mortality declined exponentially from 1401000 in children with a nutritional state of $55^{\prime \prime}$ "of NCHS standard to 10.51000 in those with a nutritional state of $75^{\circ}$ " and over. This gave a relative $\mathbb{D}$ risk of 14 for severely malnourished children compared with their well nourished counterparts.

Table III shows the mortality rates by age ( 2 years or less) and nutritional state. No deaths were reported in the 3 year age group. In $\overline{\bar{a}}$ children aged less than 2 years nutritional state had only a slight effect $\frac{\text { a }}{2}$ on mortality. By contrast, in the 2 year age group one in three of the severely malnourished children and one in 10 of the moderately mal- $\frac{\bar{\sigma}}{\bar{\sigma}}$ nourished children died during the follow up period. Table IV gives $\frac{\bar{s}}{5}$ the lay reports of the causes of death in the severely malnourished $\mathbb{D}$ children in the 2 year age group. These reports, which are collected independently for the registration system, showed that in every case os in which a report was available the child had died after prolonged sick- $\overrightarrow{0}$ ness. This shows that severely malnourished children with chronic enteric illness are likely to die.

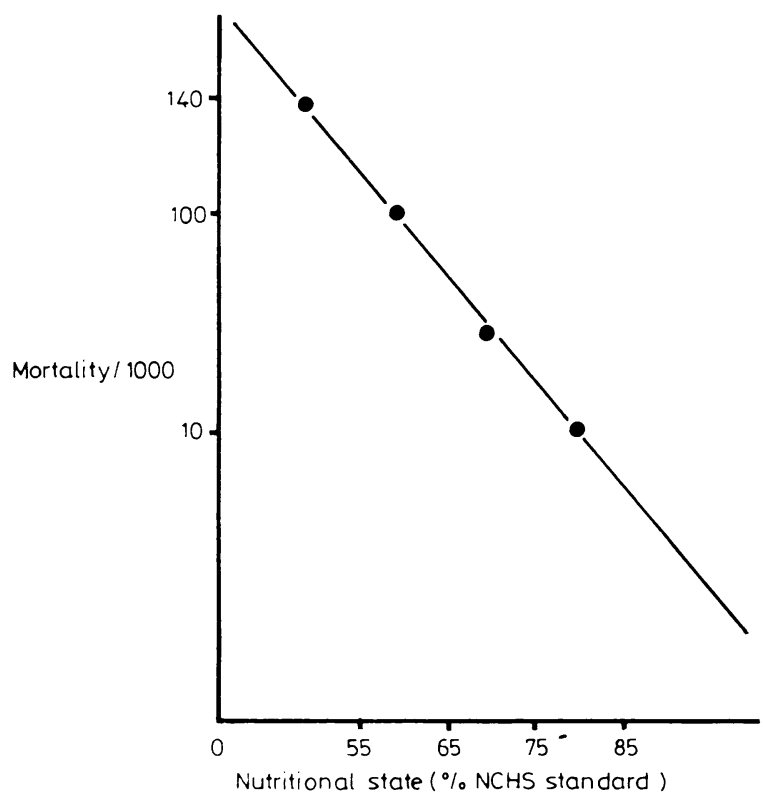

FIG 3-Yearly mortality rates (per 1000) of children with various nutritional states. (Log scale.)

TABLE III-Mortality rate and nutritional state of children

\begin{tabular}{lcccc}
\hline $\begin{array}{l}\text { Nutritional state } \\
(" \% \text { NCHS } \\
\text { standard) }\end{array}$ & $\begin{array}{c}\text { Children } \\
\text { admitted } \\
\text { aged 2 2 years }\end{array}$ & $\begin{array}{c}\text { Mortality } 1000 \\
\text { for children } \\
\text { aged 2 years }\end{array}$ & $\begin{array}{c}\text { Children } \\
\text { admitted } \\
\text { aged 2 years }\end{array}$ & $\begin{array}{c}\text { Mortality 1000 } \\
\text { for children } \\
\text { aged 2 years }\end{array}$ \\
\hline $\begin{array}{l}555 \\
56-65\end{array}$ & 37 & $27 \cdot 0$ & 25 & $320 \cdot 0$ \\
$\geqslant 66$ & 124 & $48 \cdot 4$ & 29 & $103 \cdot 4$ \\
\hline Total & 277 & $21 \cdot 7$ & 39 & 0 \\
\hline
\end{tabular}

TABLE IV-Ages and nutritional states of eight severely malnourished children who died and lay reports of causes of death

\begin{tabular}{|c|c|c|c|}
\hline $\begin{array}{l}\text { Case } \\
\text { No }\end{array}$ & Age & $\begin{array}{l}\text { Nutritional state } \\
\left({ }_{0} \text { NCHS }\right. \\
\text { standard })\end{array}$ & Lay report of cause of death \\
\hline 1 & 2 years 3 months & 33 & Diarrhoea \\
\hline 2 & 2 years 4 months & 47 & Dysentery with mucus and fever \\
\hline 3 & 2 years 4 months & 49 & $\begin{array}{l}\text { Measles for four days followed by } \\
\text { dysentery and diarrhoea for one } \\
\text { month }\end{array}$ \\
\hline 4 & 2 years 6 months & 50 & $\begin{array}{l}\text { Dysentery with mucus; became weak } \\
\text { day by day and died }\end{array}$ \\
\hline 5 & 2 years 6 months & 48 & Blood dysentery for two months \\
\hline 6 & 2 years & 50 & Unknown \\
\hline 7 & 2 years 2 months & 49 & Chronic dysentery for two months \\
\hline 8 & 2 years 6 months & 50 & Fever for a long time \\
\hline
\end{tabular}




\section{Discussion}

This study provides a clear relation between the mortality rate after recovery from diarrhoea and the nutritional state. Severely malnourished children had a 14 times greater risk of death than their nutritionally better off counterparts. More of the excess deaths occurred within three months after discharge from hospital. Chen et al, in their study of children aged 13 to 23 months followed up for two years in a similar rural community, also found a relation between anthropometric measurements and subsequent mortality. ${ }^{3}$

Interestingly, in our study the excess deaths were confined to the 2 year age group. In children aged less than 2 years there were no excess deaths, nor was mortality affected by nutritional state. By contrast, in the 2 year age group all the deaths occurred in lower nutritional categories. An explanation for these differences might be that nutrition in children aged under 2 years is related to birth weight, whereas malnutrition in children aged 2 years and over is related to food. Also breast feeding is universal and prolonged in this area, ${ }^{7}$ which might have protected the children aged under 2 years against reinfection and contributed to nutritional rehabilitation. Children aged 2 years or more are dependent on other types of food and are neither protected against reinfection nor have sufficient or appropriate food to be rehabilitated nutritionally. Therefore, when a population is universally breast fed, classification of children by single years or even half a year will be methodologically better for nutritional studies.

Another finding, based on lay reporting of causes of death, shows that even in severely malnourished children death occurs after a prolonged illness, mostly of an enteric nature. This would allow enough time for treatment of the disease as well as for nutritional rehabilitation to prevent such deaths.

Our findings indicate a need to integrate diarrhoeal treatment with nutritional rehabilitation and home follow up care for children aged 2 years and severely malnourished. Since death is not immediate, the programme should be implemented easily and successfully.

This research was supported by the International Centre for Diarrhoeal Disease Research, Bangladesh (ICDDR,B). ICDDR,B is supported by countries and agencies which share its concern about the impact of diarrhoeal diseases on the developing world. Current donors giving assistance to ICDDR,B are: Arab Gulf Fund, Australia, Bangladesh, France, Japan, Saudi Arabia, Sweden, Switzerland, United Kingdom, and USAID.

\section{References \\ ${ }^{1}$ Puffer RR, Serrano CV. Patterns of mortality in childhood. Washington, DC: Pan American Health Organisation, World Health Organisation, 1973. \\ 2 Somer A, Loewenstein MS. Nutritional status and mortality: a prospective validation of the quack stick. Am $\mathcal{f}$ Clin Nutr 1975;28:287-92. \\ ${ }^{3}$ Chen LC, Chowdhury AKMA, Huffman SL. Anthropometric assessment of energy protein malnutrition and subsequent risk of mortality among pre-school aged children. Am f Clin Nutr 1980;33:1836-45. \\ ' Ruzicka LT, Chowdhury AKMA. Demographic surveillance system- Matlab. Vol 1. Method and procedures. Dacca: International Centre for Diarrhoeal Disease Research, Bangladesh, 1978. (Scientific report No 9.) \\ 'US Department of Health, Education, and Welfare, Public Health Service. NCHS growth curves for children, birth-18 years, United States. Washington, DC: DHEW, 1980. (DHEW publication No (PHS) 78-1650.) \\ ${ }^{6}$ Samad A, Sheikh K, Sardar AM, Beeke S, Chen LC. Demographic surveillance system-Matlab. Vol 6. Vital events and migration-1977. Dacca: International Centre for Diarrhoeal Disease Research, Bangla- desh, 1979. (Scientific report No 18.) \\ ' Huffman SL, Chowdhury AKMA, Chakraborty J, Simposon NK. Breastfeeding patterns in rural Bangladesh. Am f Clin Nutr 1980;33 144-54.}

(Accepted 26 fuly 1983)

\title{
Comparison between penicillamine and sulphasalazine in rheumatoid arthritis: Leeds-Birmingham trial
}

\author{
V C NEUMANN，K A GRINDULIS，S HUBBALL，B MCCONKEY， V WRIGHT
}

\begin{abstract}
Sulphasalazine was first formulated by Svartz in the early 1940s, specifically for use as a remission inducing drug in rheumatoid arthritis. After the publication of an unfavourable trial, however, the drug was restricted to patients with ulcerative colitis. In the late 1970 s sulphasalazine was re-examined in rheumatoid arthritis and favourable results reported in "open" trials. A double blind controlled trial was therefore conducted comparing enteric coated sulphasalazine and $D$-penicillamine in patients with active rheumatoid arthritis.
\end{abstract}

A total of 63 patients were recruited in two centres; 31

Rheumatism Research Unit, University of Leeds, Leeds LS2 9PJ

V C NEUMANN, MB, MRCP, senior registrar

V WRIGHT, $M D$, FRCP, professor

Dudley Road Hospital, Birmingham

K A GRINDULIS, $M B$, MRCP, registrar

S HUBBALL, BSC, AIMLS, research scientist

B MCCONKEY, DM, FRCP, consultant physician

Correspondence to: Dr V C Neumann. were treated with sulphasalazine and 32 received penicillamine. After 16 weeks' treatment both drugs had produced significant improvements in clinical score, pain score measured on a visual analogue scale, grip strength, Ritchie articular index, erythrocyte sedimentation rate, and serum $C$ reactive protein concentration. Nausea was the major side effect in the sulphasalazine treated group. No potentially dangerous effects of sulphasalazine were encountered in contrast with those seen in the penicillamine group.

The results suggest that sulphasalazine is an effective and safe drug capable of producing remissions in active rheumatoid arthritis. They also lend confidence to the use of preliminary "open" trials as a means of screening for remission inducing drugs in rheumatoid arthritis.

\section{Introduction}

In 1938 contemporary medical thinking held that rheumatoid arthritis was an infection and therefore potentially responsive to antibiotics. Attempts to treat the disease with sulphonamides (the only antibiotics then available), however, had failed. Salicylates were widely used for relief of symptoms but had little 